\title{
DESAIN MODUL PENGAYAAN PADA MATA PELAJARAN KONSTRUKSI BETON BERTULANG SESUAI DENGAN SNI BETON UNTUK MENINGKATKAN KEAKTIFAN DAN NILAI TIGA RANAH BELAJAR SISWA KELAS XI TEKNIK KONSTRUKSI BATU BETON SMK NEGERI 2 SURAKARTA DENGAN MODEL INQUIRY LEARNING
}

\author{
Razan Ihtifazhuddan ${ }^{1}$, Ernawati Sri Sunarsih ${ }^{2}$, Sutrisno $^{3}$ \\ razan.fkip@gmail.com
}

\begin{abstract}
Abstrak : Tujuan penelitian ini adalah untuk mengetahui ada atau tidaknya peningkatan keaktifan dan nilai pada tiga ranah belajar dengan penerapan modul pengayaan dengan model pembelajaran Inquiry Learning pada mata pelajaran Konstruksi Beton Bertulang siswa kelas XI Teknik Konstruksi Batu Beton SMK Negeri 2 Surakarta. Subjek penelitian adalah siswa kelas XI Konsentrasi Teknik Konstruksi Batu Beton SMK Negeri 2 Surakarta, dalam satu kelas yang terdiri dari 31 siswa. Penelitian ini adalah Penelitian Tindakan Kelas. Teknik pengumpulan data yang digunakan antara lain observasi, teknik tes, dokumentasi, dan wawancara. Teknik analisis data dilakukan secara deskriptif kualitatif, alur yang dilalui meliputi reduksi data, penyajian data dan penarikan kesimpulan. Hasil penelitian ini adalah nilai ranah kognitif rata-rata 79,77 dengan ketuntasan 90,32\%. Hasil nilai ranah afektif didapatkan nilai rata-rata 81,05 dengan ketuntasan $80,65 \%$. Sedangkan nilai ranah psikomotorik didapatkan rata-rata 80,09 dengan ketuntasan $84 \%$. Siswa yang aktif $87,10 \%$ dan siswa yang belum aktif sebesar $12,90 \%$. Kesimpulan bahwa penerapan pembelajaran dengan modul pengayaan dengan model pembelajaran Inquiry Learning dapat meningkatkan keaktifan dan hasil belajar pada mata pelajaran Konstruksi Beton Bertulang siswa kelas XI Teknik Konstruksi Batu Beton SMK Negeri 2 Surakarta.
\end{abstract}

Kata kunci : modul pengayaan, keaktifan, ranah belajar, inquiry learning

${ }^{3}$ Pengajar Program Studi Pendidikan Teknik Bangunan FKIP Universitas Sebelas Maret 


\title{
DESAIN OF ENRICHMENT MODULE AT CONCRET REINFORCEMENT CONSTRUCTION COMPATIBLE WITH CONCRETE SNI TO INCREASE ACTIVITY AND LEARNING RESULT STUDENTS OF CLASS XI CONCRETE CONSTRUCTION ENGINEERING SMK NEGERI 2 SURAKARTA WITH INQUIRY LEARNING MODEL
}

\author{
Razan Ihtifazhuddan ${ }^{1}$, Ernawati Sri Sunarsih ${ }^{2}$, Sutrisno $^{3}$ \\ razan.fkip@gmail.com
}

\begin{abstract}
The purpose of this research is to know the improvement of activity and learning outcomes with the application of enrichment module with instructional model of Inquiry Learning on the subjects of Concrete Construction of Student Class XI Concrete Construction Construction of SMK Negeri 2 Surakarta. The subject of the research is the students of class XI Concentration of Concrete Construction Technique of SMK Negeri 2 Surakarta, in a class consisting of 31 people.. This research is a Classroom Action Research. Data collection used, among others, observation, test techniques, documentation, and interviews. The data analysis is done descriptively qualitative, the troughs include data reduction, data presentation and conclusion. The results of this study are as follows, from 31 students in one class, the average cognitive domain score was 79,77 with percentage of $90,32 \%$. Then for affective domain results obtained an average value of $81.05 \%$ with a percentage of mastery $80.65 \%$. While the psychomotor domain score obtained an average of 80.09 with the percentage mastery $84 \%$. The percentage of active students is $87.10 \%$ or as many as 27 students and the percentage of inactive students is $12.90 \%$ or as many as 4 students. So, it can be concluded that the application of learning with enrichment module with instructional model Inquiry Learning can improve the activity and learning result on the subjects Concrete Reinforcement Construction students of class XI Concrete Construction Engineering SMK Negeri 2 Surakarta.
\end{abstract}

Keywords: enrichment module, activity, learning result, inquiry learning 


\section{PENDAHULUAN}

Masalah yang timbul dalam proses belajar mengajar disebabkan pemanfaatan modul oleh guru yang sangat minimal dan modul yang dibuat hanya sebagai kelengkapan administrasi mengajar. Selain pada pemanfaatan modul yang sangat minimal, pada saat menyampaikan materi guru masih menggunakan metode ceramah satu arah. Dengan demikian siswa kurang aktif dalam proses pembelajaran yang masih didominasi oleh guru dengan metode pembelajaran ceramah satu arah. Modul yang digunakan guru mata pelajaran juga masih menggunakan acuan pada PBI 1971 NI-2, yang saat ini PBI 1971 NI-2 sudah disempurnakan dengan peraturan SNI Beton Nomor 03-2847-2002.

Demikian pula dengan bahan ajar guru, seharusnya di era yang modern dan era pembaruan ilmu, bahan ajar yang di Acuan yang digunakan guru konstruksi beton bertulang sudah harus berbasis SNI Beton Nomor 03-28472002. Selaku pengelola kegiatan siswa, peranan guru sangatlah penting dalam membimbing dan membantu siswa selama proses pembelajaran. Dengan demikian guru dapat meningkatkan keaktifan dan hasil belajar siswa dengan menggunakan modul pengayaan pada mata pelajaran konstruksi beton bertulang sesuai dengan SNI Beton Nomor 03-28472002 dengan model belajar Inquiry Learning.

Berdasarkan latar belakang masalah tersebut, maka peneliti merumuskan masalah yang akan diteliti pemanfaatan modul oleh guru yang akan dipadukan dengan model Inquiry yaitu : 1) Apakah penerapan pembelajaran dengan modul pengayaan dengan model pembelajaran Inquiry Learning dapat meningkatkan keaktifan pada mata pelajaran Konstruksi Beton Bertulang siswa kelas XI Teknik Konstruksi Batu Beton SMK Negeri 2 Surakarta. 2) Apakah penerapan pembelajaran dengan modul pengayaan dengan model pembelajaran Inquiry Learning dapat meningkatkan nilai pada ranah kognitif, ranah afektif dan ranah psikomotor pada mata pelajaran Konstruksi Beton Bertulang siswa kelas XI Teknik Konstruksi Batu Beton SMK Negeri 2 Surakarta.

Menurut Oemar Hamalik (2013: 54) pembelajaran adalah suatu kombinasi yang tersusun meliputi unsur - unsur menusiawi, fasilitas, perlengkapan, dan prosedur yang saling mempengaruhi untuk mencapai tujuan dari pembelajaran itu sendiri. Dalam suatu proses pembelajaran terjadi interaksi antara guru dan siswa, guru dan siswa merupakan unsur terpenting dalam suatu proses pembelajaran. Proses pembelajaran akan dikatakan berhasil apabila selama proses pembelajaran ditunjang fasilitas, dan hakikat pembelajaran.

Hakekat pembelajaran sendiri
mengarahkan terjadinya proses
pembelajaran yang sesuai dengan
sistem yang akan memberikan
pengalaman belajar kepada siswa.
Program yang dirancang harus terdiri
tujuan pembelajara, isi pembelajaran
dan sistem penyajian yang akan


diimplementasikan dalam realisasi proses pembelajaran.

Jadi dapat disimpulakan bahwa pembelajaran merupakan proses interaksi belajar mengajar yang melibatkan komponen - komponen pembelajaran yang meliputi tujuan pembelajaran, guru sebagai pengajar,

Saripuddin (dalam Abbas, 2000:10) mendefinisikan model pembelajaran sebagai kerangka konseptual yang menggambarkan prosedur yeng sistematis dalam mengkoordinasikan pengalaman belajar untuk mencapai tujuan tertentu, dan berfungsi sebagai pedoman bagi perancang dan para guru dalam merencanakan dan melaksanakan aktivitas belajar-mengajar. Model pembelajaran akan menentukan arah guru dalam mendesain aktivitas belajar-mengajar di dalam kelas.

Sedangkan, Joyce dan Weil, M. (dalam Abbas, 2000:10) mendefinisikan model pembelajaran adalah suatu pola yang digunakan sebagai pedoman dalam merencanakan pembelajaran di kelas atau pembelajaran dalam setting tutorial dan untuk menentukan perangkat-perangkat pembelajaran termasuk di dalamnya buku-buku, film, komputer, kurikulum dan lain-lain. Model pembelajaran diharapkan menjadi pedoman guru dalam menyusun perangkat pembelajaran. Dengan demikian guru dapat menentukan media pembelajaran yang sesuai dengan kondisi kelas.

Arends (dalam Abbas, 2000:10) menyatakan bahwa model pembelajaran mengacu kepada pendekatan pembelajaran termasuk di dalamnya tujuan pembelajaran, tahaptahap kegiatan pembelajaran, peserta didik sebagai subyek yang menerima pembelajaran, materi pelajaran, metode, media, dan evaluasi. Komponen - komponen tersebut saling mempengaruhi satu dengan lainya dan saling berhubungan dalam proses pembelajaran untuk mencapai tujuan pembelajaran.

lingkungan pembelajaran dan pengelolaan kelas. Model pembelajaran lebih menenkankan pada proses pembelajaran yang berfokus pada tahap-tahap kegiatan, lingkungan dan pengelolaan kelas dalam mencapai tujuan pembelajaran.

Berdasarkan definisi dari para ahli, model pembelajaran merupakan kerangka konseptual yang menggambarkan prosedur sistematik dalam mengkoordinasikan pengalaman belajar untuk mencapai tujuan belajar, yang berfungsi sebagai pedoman gurudalam merancang dan melaksanakan kegiatan pembelajaran, mengelola lingkungan pembelajaran dan mengelola kelas. Dalam merancang dan melaksanakan pembelajaran diperlukan perangkat pembelajaran yang dapat disusun dan dikembangkan oleh guru. Perangkatperangkat itu meliputi buku guru, buku siswa, lembar tugas/kerja siswa, media bantu seperti komputer, transparansi, film, pedoman pelaksanaan pembelajaran, seperti kurikulum dan lain-lain.

Model pembelajaran inquiry adalah rangkaian kegiatan pembelajaran yang menekankan pada proses berpikir secara kritis dan analisis untuk mencari dan menemukan sendiri jawaban dari suatu masalah yang dipertanyakan" (Sanjaya, 2006:194). Siswa dituntut untuk berfikir kritis dalam suatu pokok masalah, siswa harus menganalisis dan 
menemukan jawaban atas masalah yang diberikan guru.

Menurut piaget (mulyasa, 2008:108) bahwa model pembelajaran inquiry adalah model pembelajaran yang mempersiapkan siswa pada situasi untuk melakukan eksperimen sendiri secara luas agar melihat apa yang terjadi, ingin melakukan sesuatu, mengajukan pertanyaan-pertanyaan, dan mencari jawabannya sendiri, serta menghubungkan penemuan yang satu dengan penemuan yang lain, membandingkan apa yang ditemukannya dengan yang ditemukan siswa lain. Model pembelajaran inquiry menuntut siswa untuk menuntut siswa untuk merumuskan masalah dan mengajukan hipotesis terhadap masalah yang harus diselesaikan.

Dengan melihat kedua pendapat di atas, maka dapat disimpulkan bahwa pembelajaran inquiry adalah model pembelajaran yang mempersiapkan siswa pada situasi untuk melakukan eksperimen sendiri sehingga dapat berpikir secara kritis untuk mencari dan menemukan jawaban dari suatu masalah yang dipertanyakan.

langkah-langkah berikut sebagai bentuk model pembelajaran yang disebut model pembelajaran inkuiri. Sutikno (2014:83) mengemukakan langkah-langkah inquiry learning sebagai berikut:

1. Orientasi terhadap Masalah

2. Merumuskan Masalah

3. Mengajukan Hipotesis

4. Mengumpulkan Informasi (Data)

5. Menguji Hipotesis

6. Menyimpulkan

Modul pengayaan merupakan satuan program belajar mengajar yang terkecil, yang dipelajari oleh siswa sendiri secara perseorangan atau diajarkan oleh siswa kepada dirinya sendiri (self-instructional) (Winkel, 2009:472). Modul pembelajaran merangsang siswa agar dapat belajar mandiri baik secara perseorangan maupun kelompok. Modul yang dibuat harus terstrukur agar siswa dapat belajar mandiri dari modul yang ada.

Modul pembelajaran adalah bahan ajar yang disusun secara sistematis dan menarik yang mencakup isi materi, metode dan evaluasi yang dapat digunakan secara mandiri untuk mencapai kompetensi yang diharapkan (Anwar, 2010). Modul harus berisi informasi yang menarik agar siswa tertarik menggunakan modul sebagai sumber belajar. Modul yang dibuat harus berisi materi dan bahan evaluasi mencakup kompetensi yang diharapkan

Menurut Goldschmid, Modul pembelajaran sebagai sejenis satuan kegiatan belajar yang terencana, di desain guna membantu siswa menyelesaikan tujuan-tujuan tertentu. Modul adalah semacam paket program untuk keperluan belajar (Wijaya, 1988:128). Pengajaran modul merupakan usaha penyelanggaraan pengajaran individual yang memungkinkan siswa menguasai satu unit bahan pelajaran sebelum dia beralih kepada unit berikutnya. Berdasarkan beberapa pengertian modul di atas maka dapat disimpulkan bahwa modul pembelajaran adalah salah satu bentuk bahan ajar yang dikemas secara sistematis dan menarik sehingga mudah untuk dipelajari secara mandiri.

Menurut Kamus Besar Bahasa Indonesia berarti giat (bekerja, 
berusaha). Keaktifan adalah sesuatu kegiatan belajar yang ditandai adanya keterlibatan secara optimal, baik intelektual, emosional, dan fisik (Aunurrahman, 2009). Lingren dalam Daryanto dan Rahardjo (2012) keaktifan adalah interaksi di antara siswa dengan guru dan siswa dengan siswa lainnya. Dari pendapat di atas dapat disimpulkan bahwa keaktifan adalah keadaan dimana siswa dapat berinteraksi atau keterlibatan aktif dalam bentuk sikap pada proses belajar.

Nilai Tiga Ranah Belajar adalah nilai yang telah dicapai seseorang dalam melakukan kegiatan. Gagne (1985:40) menyatakan bahwa Prestasi Belajar dibedakan menjadi lima aspek, yaitu : kemampuan intelektual, strategi kognitif, informasi verbal, sikap dan keterampilan. Menurut Bloom dalam Suharsimi Arikunto (1990:110) bahwa hasil belajar dibedakan menjadi tiga aspek yaitu kognitif, afektif dan psikomotorik.

\section{METODE PENELITIAN}

Tempat penelitian tindakan kelas pada penelitian ini dilaksanakan di SMK Negeri 2 Surakarta. Waktu pelaksanaan penelitian dilakukan mulai bulan Agustus 2017 sampai bulan September 2017. Subjek penelitian ini adalah guru dan siswa kelas XI TKBB SMK Negeri 2 Surakarta.

Teknik pengumpulan data yang digunakan yaitu dengan observasi, dokumentasi, tes dan wawancara. Observasi dilakukan pada setiap siklusnya untuk mencari data terhadap keaktifan siswa dan hasil belajar. Teknik tes tertulis dilaksanakan untuk mengetahui hasil belajar ranah kognitif. Dokumentasi digunakan untuk mengumpulkan dan mencari data dari dokumen yang sudah ada di sekolah. Wawancara pada siswa digunakan untuk mengungkap bagaimana cara guru menggunakan bahan ajar, menerangkan materi dan mengelola kelas selama proses pembelajaran.

Untuk menjamin pemantapan dan kebenaran data yang dikumpulkan dan dicatat dalam penelitian maka dipilih dan ditemukan cara -cara yang tepat untuk mengembangkan validitas data yang diperolehnya. Dalam penelitian ini teknik pengumpulan data yang akan digunakan adalah teknik Triangulasi.

Penelitian ini menggunakan triangulasi data dengan jalan memanfaatkan guru, siswa, dan observer untuk keperluan pengecekan kembali derajat kepercayan data. Pemantapan lainnya dalam hal ini adalah guru Konstruksi Beton Bertulang dan kepala sekolah itu sendiri dapat, membantu mengurangi kesalahan dalam pengumpulan data.

Selain menjamin kemantapan data, validasi juga dilakukan pada modul yang di desain, rencana proses pembelajaran (RPP), dan lembar observasi proses belajar-mengajar pada saat siklus penelitian. Seluruh instrumen yang digunakan sudah tervalidasi oleh ahli media, ahli materi dan ahli pendidikan

Indikator keaktifan siswa yang ditargetkan dalam penelitian ini sebesar $75 \%$ siswa yang aktif dalam sau kelas. Sedangkan untuk penilaian hasil belajar siswa, sedangkan untuk ranah kognitif, afektif, dan psikomotorik sebanyak $75 \%$ siswa memperoleh nilai 76,00.

Adapun prosedur penelitian dilakukan dengan siklus PTK secara terperinci mulai dari perencanaan, pelaksanaan tindakan, pengamatan, dan refleksi evaluasi yang bersifat siklus 
berulang-ulang, sampai mencapai indikator penelitian.

\section{HASIL DAN PEMBAHASAN}

Hasil tindakan antar siklus ini meliputi hasil tindakan siswa sebelum diterapkannya modul pengayaan dipadukan dengan model pembelajaran Inquiry (pra siklus) dan sesudah diterapkannya modul pengayaan dipadukan dengan model pembelajaran Inquiry (siklus I dan siklus II). Keaktifan dan nilai pada tiga ranah belajar siswa dalam mengikuti pembelajaran mengalami peningkatan dari siklus I menuju siklus II.

Dari hasil penelitian dapat dilihat bahwa penerapan modul pengayaan dipadukan dengan model pembelajaran Inquiry pada keaktifan dan nilai pada ranah belajar siswa mengalami perbaikan setiap siklusnya. Peningkatan setiap indikator dalam penelitian dapat disajikan sebagai berikut:

Tabel 1. Perandingan Keaktifan Siswa

\begin{tabular}{lcc}
\multicolumn{1}{c}{ Kegiatan } & Aktif & Tidak Aktif \\
\hline Pra Siklus & $19 \%$ & $81 \%$ \\
\hline Siklus I & $35,48 \%$ & $64,52 \%$ \\
\hline Siklus II & $87,10 \%$ & $12,90 \%$ \\
\hline
\end{tabular}

Tabel 2. Perandingan Nilai Ranah Belajar Siswa

\begin{tabular}{lccc}
\hline Kegiatan & Kognitif & $\begin{array}{c}\text { Psikomo } \\
\text { torik }\end{array}$ & Afektif \\
\hline Pra Siklus & $0 \%$ & $52 \%$ & $41,94 \%$ \\
\hline Siklus I & $51,61 \%$ & $71 \%$ & $61,29 \%$ \\
\hline Siklus II & $90,32 \%$ & $84 \%$ & $80,65 \%$ \\
\hline
\end{tabular}

Proses pelaksanaan tindakan pra siklus peneliti mengadakan observasi kondisi proses pembelajaran dan melakukan ujian tertulis. Hasil yang diperoleh bahwa siswa cenderung pasif dalam mengikuti proses pembelajaran. Dalam proses pembelajaran masih terdapat beberapa siswa yang sibuk dengan kegiatannya sendiri baik mengobrol dengan teman, tiduran dan bermain gadget pada saat melaksanakan proses pembelajaran.

Pada tahap pra siklus nilai belajar ranah kognitif didapat nilai rata-rata kelas sebesar 44,35 dengan persentase ketuntasan 0\% (0 siswa dari 31 siswa). Dimana nilai rata-rata kelas yang diperoleh masih sangat jauh dari KKM yaitu sebesar 76. Dari keaktifan siswa dan hasil belajar siswa yang diperoleh masih jauh dengan kriteria ketuntasan yang telah ditetapkan. Hal ini terjadi karena siswa dalam mengikuti pembelajaran masih kurang aktif. Untuk menumbuhkan keaktifan siswa dalam proses pembelajaran maka perlu adanya modul sebagai media dan model pembelajaran baru dengan menggunakan model pembelajaran Inquiry. Dalam model pembelajaran Inquiry siswa dituntut untuk mencari dan menggali informasi dari pokok bahasan yang diberikan Guru melalui modul yang tersedia. Dengan demikian akan terjadi komunikasi dan kerjasama antar siswa yang diharapkan dapat meningkatkan keaktifan dan hasil belajar siswa dalam proses pembelajaran.

Keaktifan siswa dalam pelaksanaan siklus I dalam mengikuti tugas diskusi kelompok sudah cukup aktif. Keaktifan diskusi sudah cukup baik, hal ini dapat dilihat dari berkurangnya siswa yang kurang aktif dalam proses pembelajaran. Pada keaktifan siswa didapat rata-rata 
sebesar 71,06 dengan persentase siswa yang aktif $35,48 \%$ atau sebanyak 11 siswa dan presentase siswa yang belum aktif sebesar $64,52 \%$ atau sebanyak 20 siswa. Hal ini menunjukan bahwa jumlah siswa yang aktif sudah lebih banyak dibandingkan siswa yang belum aktif.

Peningkatan yang terjadi pada keaktifan siklus I ini disebabkan siswa memiliki suasana baru dalam proses pembelajaran, yang biasanya siswa belajar dengan metode ceramah satu arah dimana guru menjadi fokus utama dalam proses belajarnya, kini siswa lebih diberikan ruang untuk bereksploarsi dengan modul yang diberikan dan aktif berdiskusi dengan diterapkannya model pembelajaran inquiry. Sehingga suasana belajar dikelas terlihat lebih aktif, hal disebabkan interaksi antara guru dan siswa menjadi lebih komunikatif, meskipun masih ada sebagian siswa yang merasa belum nyaman dengan teman satu kelompoknya.

Pada hasil ranah kognitif didapat rata-rata sebesar 71,94 dengan persentase ketuntasan $51,61 \%$ dengan 16 siswa yang sudah memenuhi nilai KKM dari 31 siswa dalam satu kelas. Hal ini menunjukan adanya kenaikan signifikan dari persentase ketuntasan pra siklus. Dimana saat melakukan ujian tertulis pada tahap pra siklus, terlihat belum ada siswa yang mendapat nilai diatas nilai KKM. Dengan demikian setelah diterapkannya modul yang dipadu dengan model pembelajaran Inquiry, terdapat kenaikan sebesar 51,61\% dari tahap pra siklus. Ini menunjukan bahwa dengan menggunakan modul dipadu dengan model inquiry membuat siswa lebih mudah memahami pokok bahasan materi. Meskipun sudah mengalami peningkatan nilai dibandingkan prasiklus, peningkatan yang dicapai belum mencapai indikator penelitian. Hasil ranah afektif didapat persentase ketuntasan $61,29 \%$ dengan 19 siswa yang sudah memenuhi nilai KKM dari 31 siswa yang ada dalam satu kelas. Pada penilain afektif siklus I belum memenuhi kriteria ketuntasan yang telah ditetapkan.

Hasil ranah psikomotorik didapat persentase ketuntasan $71 \%$ dengan 22 siswa yang sudah memenuhi nilai KKM dari 31 siswa yang ada dalam satu kelas. Karena sebagian siswa merasa bosan dengan anggota kelompok dengan urut nomor absen, ini juga mempengaruhi pada penilaian ranah psikomotor. Pada pelaksanaan siklus II keaktifan diskusi mengalami peningkatan karena siswa sudah ikut berperan aktif dalam mengikuti tugas diskusi meskipun masih ada beberapa siswa yang kurang aktif. Untuk keaktifan bertanya pada siklus II juga mengalami peningkatan, siswa sudah mulai berani dan aktif bertanya apabila mengalami kesulitan. Keaktifan siswa pada siklus 2 didapat rata-rata sebesar 79,51 dengan persentase siswa yang aktif $87,10 \%$ atau sebanyak 27 siswa dan presentase siswa yang belum aktif sebesar $12,90 \%$ atau sebanyak 4 siswa. Hal ini menunjukan bahwa jumlah siswa yang aktif sudah lebih banyak dibandingkan siswa yang belum aktif.

Permasalahan yang guru berikan sehingga keaktifan siswa pada siklus II mengalami peningkatan dari siklus I. Pada hasil ranah kognitif didapat ratarata sebesar 79,77 dengan persentase ketuntasan 90,32\% dengan 28 siswa 
yang sudah memenuhi nilai KKM dari 31 siswa dalam satu kelas. Hal ini menunjukan adanya kenaikan signifikan dari persentase ketuntasan siklus I. Dimana saat melakukan ujian tertulis pada tahap siklus I, terlihat siswa yang mendapat nilai diatas nilai KKM hanya sebanyak 15 siswa. Dengan demikian setelah dilakukan refleksi tindakan dari siklus I, terdapat kenaikan sebesar $38,71 \%$ dari tahap siklus I. Dimana pada tahap siklus I terlihat persentase ketuntuasan ranah kognitif sebesar 51,61\% naik sebesar $38,71 \%$ pada tahap penelitian siklus II.

Penyempurnaan modul pengayaan dengan cara pemberian judul pokok bahasan menjadikan siswa lebih paham apa yang harus dipelajari, sehingga siswa mengetahui apa yang dipelajari saat pertemuan ini dan pertemuan yang akan datang. Dikarenakan modul yang digunakan pada saat siklus 1 belum memberikan penegasan pada bagian judul pokok bahasan.

Hasih ranah afektif didapat ratarata sebesar 81,05 dengan persentase ketuntasan $80,65 \%$ dengan 25 siswa yang mendapat nilai diatas KKM dari 31 siswa dalam satu kelas. Dengan semangat kerjasama yang tinggi dalam proses berdiskusi membuat siswa menjadi lebih kompak dalam menyelesaikan diskusi dan terlihat lebih presentatif pada saat presentasi hasil kelompok. Siswa menjadi lebih kritis dan tanggap dalam setiap presentasi dari kelompok lain yang sedang memaparkan hasil diskusinya. Sehingga proses pembelajaran pada siklus II terlihat sangat komunikatif dibandingkan dengan siklus I.
Pada hasil ranah psikomotorik didapat rata-rata sebesar 80,03 dengan persentase ketuntasan $84 \%$ dengan 26 siswa yang mendapat nilai diatas KKM dari 31 siswa dalam satu kelas. Dikarenakan suasana anggota kelompok yang baru juga mempengaruhi peningkatan pada ranah psikomotor siklus II. Siswa terlihat lebih nyaman dengan anggota kelompok baru yang menunjang semangat kerjasama dalam berdiskusi. Dengan semangat kerjasama yang tinggi, maka siswa terlihat lebih serius dalam memecahkan masalah yang guru berikan dengan kelompok diskusinya.

Keaktifan siswa dan hasil belajar siswa siklus II mengalami peningkatan sangat baik. Siswa sangat antusias dalam mengikuti proses pembelajaran. Hal ini dapat dilihat dari keaktifan siswa dalam bertanya ketika mengalami kesulitan dalam penyelesaian tugas diskusi kelompok maupun pada saat presentasi kelompok. Siswa tidak lagi malu bertanya kepada guru apabila mengalami kesulitan dan aktif memberikan pendapat maupun pertanyaan pada kelompok saat presentase. Kerjasama antar siswa sangat menonjol dalam menganalisis soal yang diberikan oleh guru.

Hasil penelitian dengan menerapkan modul Konstruksi Beton Bertulang yang efektif dan komunikatif dipadu dengan model pembelajaran Inquiry pada kelas XI TKBB SMK Negeri 2 Surakarta terbukti dapat meningkatkan keaktifan dan hasil belajar siswa. Semua aspek hasil belajar seperti ranah kognitif, ranah afektif, dan ranah pesikomotorik mengalami peningkatan nilai ketuntasannya. Hal ini sesuai dengan 
kriteria ketuntasan yang telah ditetapkan oleh peneliti.

\section{SIMPULAN}

Berdasarkan hasil penelitian dengan menerapkan modul pengayaan dipadukan dengan model Inquiry dapatkan disimpulkan sebagai berikut:

1. Dengan penerapan modul penganyaan dipadu model Inquiry Learning dapat meningkatkan keaktifan siswa pada mata pelajaran Konstruksi Beton Bertulang siswa kelas XI Teknik Konstruksi Batu Beton SMK Negeri 2 Surakarta.

2. Pada penerapan modul penganyaan dipadu model Inquiry Learning dapat meningkatkan nilai pada tiga ranah belajar siswa pada mata pelajaran Konstruksi Beton Bertulang siswa kelas XI Teknik Konstruksi Batu Beton SMK Negeri 2 Surakarta. Pada ranah kognitif didapatkan persentase ketuntasan sebesar $\quad 90,32 \%$, pada ranah afektif didapatkan ketuntasan sebanyak $80,65 \%$, dan pada ranah psikomotor didapatkan persentase ketuntasan sebanyak $84 \%$. Dengan demikian persentase yang didapatkan pada tiga ranah belajar sudah mencapai indikator ketercapaian yang direncanakan yaitu sebanyak $75 \%$.

\section{DAFTAR PUSTAKA}

Arikunto, Suharsimi. 2002. Prosedur Penelitian Suatu Pendekatan Praktek. Jakarta: Rineka Cipta.
Anwar, $\quad$ Ilham. 2010. Pengembangan Bahan Ajar. Bahan Kuliah Online. Bandung: Direktori UPI.

Hamalik, Oemar. 2013. Proses Belajar Mengajar. Jakarta: Bumi Aksara.

Kunandar. 2007. Guru Profesional : Implementasi Kurikulum Tingkat Satuan. Pendidikan (KTSP) dan Sukses dalam Sertifikasi Guru. Jakarta : Rajagrafindo Persada.

Mudjiono, Dimyati. 2009. Belajar dan Pembelajaran. Jakarta : Rineka Cipta

Sutikno, Sobry. 2014. Metode \& Model-Model Pembelajaran Menjadikan Proses. Jogjakarta: Pustaka Pelajar.

Wijaya, Cece,.dkk. 1988. Upaya Pembaharuan Dalam Pendidikan dan Pengajaran. Bandung: Remadja Karya.

Winkel. 2009. Psikologi Pengajaran. Yogyakarta : Media Abadi.

Wiriaatmadja, Rochiati. 2006. Metode Penelitian Tindakan Kelas. Bandung : Remaja Ros 